Egyptian Journal of Aquatic Biology \& Fisheries

Zoology Department, Faculty of Science,

Ain Shams University, Cairo, Egypt.

ISSN $1110-6131$

Vol. 24(2): 291 - 300 (2020)

www.ejabf.journals.ekb.eg

\title{
Effect of some medicinal plant extracts as molluscicidal and apoptotic agents on Biomphalaria alexandrina snails
}

\author{
Amina M. Ibrahim, Samah I. Ghoname*, Shereen M. Mansour and \\ Shadia M. El- Dafrawy \\ Department of Environmental Research and Medical Malacology, Theodor Bilharz Research \\ Institute, Egypt. \\ *Corresponding Author: samah.ghoname@gmail.com.
}

ARTICLE INFO

\section{Article History:}

Received: March 8, 2020

Accepted: March 30, 2020

Online: April 3, 2020

Keywords:

Biomphalaria alexandrina;

Schistosomiasis;

Chromosomes;

Ziziphus spina christi;

Moringa oleifera;

Tecoma stans.

\begin{abstract}
Schistosomiasis is one of the neglected tropical diseases (NTDs). The freshwater snails Biomphalaria alexandrina are the intermediate host of Schistosoma mansoni in Egypt. Controlling these snails by medicinal plants is a promising way as it is ecofriendly strategy. The objective of this study is, to evaluate the molluscicidal activity of ethanolic extracts of three medicinal plants Ziziphus spina christi, Moringa oleifera, Tecoma stans and their effects on the chromosomes and apoptotic changes of $B$. alexandrina snails in control and exposed snails. Results showed that ethanolic extracts had a molluscicidal activity on B. alexandrina, where $\mathrm{LC}_{50}$ of $Z$. spina christi, M. oleifera and T. stans were 108.7, 209.4 and $256 \mathrm{mg} / \mathrm{L}$ respectively. The meiotic stages were detected in the normal control group, the first meiotic division begins with a long prophase (chromatin network), which is subdivided into four stages; leptotene, zygotene, pachytene, and diplotene. After exposure of each plant extract, there were some alterations in zygotene stage, which was different in all exposed snails and induced apoptotic changes was observed. Notably, Z. spina christi had more condensed zygotene stage than other two plants and significantly increased the percentage of apoptosis than control group.
\end{abstract}

\section{INTRODUCTION}

Schistosomiasis is one of the neglected tropical diseases that affect more than 1.4 billion people worldwide (Rees et al., 2019). It is ranking the second widespread parasitic infection after malaria (CDC, 2018). It is caused by trematode worms of the genus Schistosoma and the freshwater snails of Biomphalaria genus acted as the intermediate hosts (Ibrahim and Sayed, 2019). Several strategies have been used to control schistosomiasis through controlling the intermediate host to reduce the transmission (Omobhude et al., 2017) either by chemical or biological control (Mostafa et al., 2005) . Recent researches focus on finding an alternative natural source instead of the chemical molluscicides (Ibrahim and Ghoname, 2018). The study of the genome at 
chromosomal level can be used to differentiate one species from another (Bakry and Garhy, 2011). Ibrahim et al. (2018) studied the chromosomes of B.alexandrina snails in control and infected state which could be helpful in understanding how host-parasite relationships in feasible and effective control measures. The subfamily Biomphalarinaeis a conservative group which has haploid chromosome numbers 18 (Park and Yong, 2014). In early study, Burch (1962) utilized preparations from the ovotestis and reported a haploid complement of $18 \mathrm{~N}$. The cytological methods were developed especially after using of hypotonic treatment of tissue samples and pretreatment with colchicine which is known as air drying technique (Thiriot-Quiévreux, 2003). Abdel-Haleem (2013) revealed that the diploid chromosome number $(2 \mathrm{~N})$ of B. glabrata and B. alexandrina each was 36 and stated that, ovotestis of these snails provided a good opportunity to study chromosomal analysis.

Apoptosis is an important physiological process that makes the cells commit suicide (Wyllie, 2010). This process is important for normal embryonic development, tissue homeostasis, and immune response from the organism. It is known as programmed cell death, which is a mechanism characterized by the loss of the vesicle membrane, the condensation of the cytoplasm and nucleus, DNA fragmentation, and cell shrinkage (Hengartner, 2000). Moreover, cells that fail to complete mitotic division or cytokinesis activate cell death (apoptosis) or cell cycle arrest pathways, which can lead to the formation of micronuclei, nucleoplasmic bridges, and binucleate cells, which is the same effect caused by destabilizing microtubule drugs, such as colcemid and nocodazole (Hayashi and Karlseder, 2013).The objective of this study is, to evaluate the molluscicidal activity of three medicinal plants $Z$. spina christi, M. oleifera, T. stans ethanolic extracts of each plant on the chromosomes and apoptotic changes of $B$. alexandrina snails in control and exposed snails.

\section{MATERIALS AND METHODS}

\section{Experimental animals (snails):}

Laboratory- bred B.alexandrina snails adult $(8-10 \mathrm{~mm})$ were obtained from Medical Malacology Laboratory, Theodor Bilharz Research Institute (TBRI), Giza, Egypt. Oven dried lettuce leaves and blue green algae (Nostoc muscorum) were used for feeding and water in the aquaria was changed weekly.

\section{2- Plant materials:}

The plants (Z. spina christi, T. stans and M. oleifera) were collected from Sinai and Orman garden in Giza, Egypt. The plants were kindly identified via Dr. Threase Labib, Consultant in Orman Botanical Garden and National Gene Bank. The collected plant leaves were air-dried, powdered and kept till being used. The ethanolic extracts from plants under investigation were carried out using the conventional standard procedures.

\section{Molluscicidal screening and chromosome preparation:}

To calculate $\mathrm{LC}_{50}$ and $\mathrm{LC}_{90}$ series of concentrations were prepared on the basis of volume/ volume as ethanolic extract of leaves of the three plants and ten B. alexandrina snails $(8-10 \mathrm{~mm}$ ) were placed in beakers for each concentration (Litchfield and Wilcoxon, 1949). Another snail group of the same size was dipped in dechlorinated water only as control. Three replicates were used, each of 10 snails, for each concentration. The exposure period was 24 hours, then, the snails were removed from the experimental test 
solution, and washed thoroughly with dechlorinated tap water and transferred to containers with fresh dechlorinated tap water for another 24 hours of recovery, and then, prepare for chromosomal study by the usual air-drying method (Park, 2011). The snails that exposed to ethanolic extract of leaves of each plant (about 10 snails for each group) and another snail group (unexposed control snails) were placed directly in $0.1 \%$ colchicine at room temperature, for one day. Ovotestis samples were cut into small pieces, squashed, and then mixed with $0.48 \% \mathrm{KCl}$ as hypotonic solution, at room temperature. After discarding all large tissue pieces, $15 \mathrm{ml}$ of the cell sediments were transferred to a centrifuge tube and incubated for 25-35 min. The $\mathrm{KCl}$ was discarded from the supernatant after another centrifugation at $2500 \mathrm{rpm}$ for 10 minutes. The cell pellet was fixed in freshly prepared mixture of absolute methanol and glacial acetic acid (3:1) for 15 minutes, and then centrifuged at $2500 \mathrm{rpm}$ with three changes of 15 minutes duration, after which the supernatant was discarded. The fixation was repeated until the supernatant was clear, Finally, 1-2 $\mathrm{ml}$ of freshly prepared fixative were added to cell pellet and 3-5 drops of cell suspension were dropped on clean wet glass slides( previously kept at $4^{\circ} \mathrm{C}$ in $70 \%$ ethanol) which is flame-dried.

\section{4- Chromosome staining:}

Conventional staining was done using 4\% Giemsa's solution for 30 - 45 minutes and examined under a high power microscope with an oil immersion and photographs were taken.

\section{5- Flow cytometric analysis:}

Flow cytometric analysis was carried out for detecting apoptosis of ovotestis in $B$. alexandrina snails. Samples were analyzed by using annexin V conjugated to FITC will bind specificially to phosphatidyl serine and thus can be used to quantify the number of cells expressing phosphatidyl serine and undergoing apoptosis and immediately analyzed by using Accuri C6 flow cytometery (Becton Dickinson, Sunnyvale, CA, USA). For cytometer analysis, tissues of the snails were washed with isotone tris EDTA buffer and homogenized in distilled water $\mathrm{pH}$ 7.5. $100 \mu \mathrm{l}$ of each cell suspension were transferred into a sterile $15 \mathrm{ml}$ polystyrene centrifuge tube. Add antibody at the recommended dilution $(10 \mu 1$ from annexin-V cat. No.556547 BD Pharmingen FITC apoptosis Kit) for each sample mix well and incubate at room for 30 minutes. Cells were washed with $2 \mathrm{ml}$ of PBS/BSA and centrifuge at $1500 \mathrm{rpm}$ for 5 minutes discard the supernatant, resuspend cells in $0.2 \mathrm{ml}$ of PBS/BSA or with $0.2 \mathrm{ml}$ of $0.4 \%$ Para formaldehyde in PBS/BSA if required (Shapiro, 2003).

\section{Statistical analysis}

LC50 and LC90 were calculated using probit analysis. Data were expressed as the mean $\pm \mathrm{SE}$. Comparison between the mean values of different parameters in the studied groups was performed using 1-way ANOVA test and Duncan multiple range tests were used to evaluate the significant difference in the concentration of the ethanolic extract. The data were considered significant if $\mathrm{P}$-value was $\leq 0.05$.

\section{RESULTS}

\section{Molluscicidal activity and chromosome stages:}

According to the sub lethal concentration $\mathrm{LC}_{50}$, the present results showed that $Z$. spina christi had the higher molluscicidal effect than $M$. oleifera and $T$. stans ethanolic extract (Table 1). 
Table 1: Molluscicidal activity of the ethanolic extracts of Ziziphus spina christi ,Tecoma stans, Moringa oleifera gainst Biomphalaria alexandrina snails.

\begin{tabular}{lcccc}
\hline Plants & LC25 & LC50 & LC90 & Slope \\
& & & & \\
\hline Ziziphus spina christi & 102.7 & 108.7 & 120.1 & 1.08 \\
& & & & \\
\hline Moringa oleifera & 198.7 & 209.4 & 229.7 & 1.1 \\
& & & & \\
\hline Tecoma stans & 227.8 & 256.0 & 309.6 & 1.18 \\
& & & & \\
\hline
\end{tabular}

The present work was done on Biomphalaria alexandrina snail by using light microscope. The first meiotic division begins with a long prophase (chromatin network) in control snails (Fig 1. A), which is subdivided into four stages leptotene (B), zygotene (C), pachytene (D), diplotene (E). The chromatin of the chromatids was stretched out very thinly. The zygotene chromosomes appear to be contracted and darkly stained than the leptotene chromosomes. At the pachytene stage, chromosomes were more condensed (Fig.1. D), at the beginning of diplotene, the homologous begin to repel one another, causing the chromosomes to separate, the chromosomes were much shorter, more contracted and quite clearly visible (Fig. 1. E). In the exposed B. alexandrina snails, had distinctly observable changes in zygotene stage, condensation of the chromosomes was variable with different forms of this stage in three plant extracts; T. stans (Fig. 2A), $M$. oleifera (Fig. 2B) and Z. Spina christi (Fig. 2C) as result the effect of lethal concentration of them. Z. spina christi had more condensed zygotene stage than other two plants.

\section{Flow cytometric analysis:}

Flow cytometric analysis illustrated that the highest percentage of apoptosis were detected in exposed snails to ethanolic extract of $Z$ spina christi which significantly increased when compared to the control and other two plants (Fig. 3-4). 

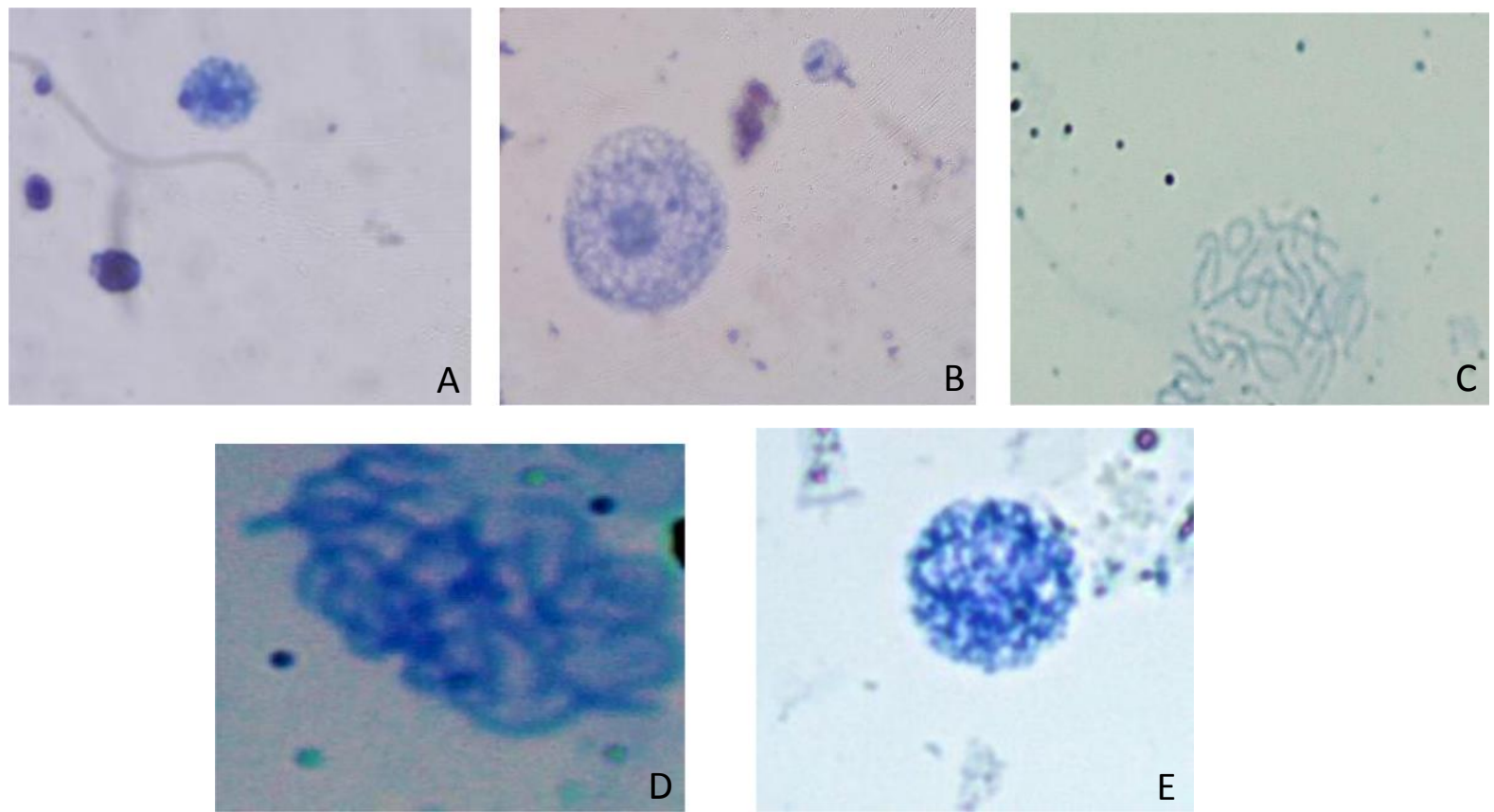

Fig.1: Light microscope of Biomphalaria alexandrina snails showing, the meiotic division of the control group, (A) a prophase (chromatin network), (B) leptotene stage (C) zygotene stage (D) Pachytene stage (E) diplotene stage.
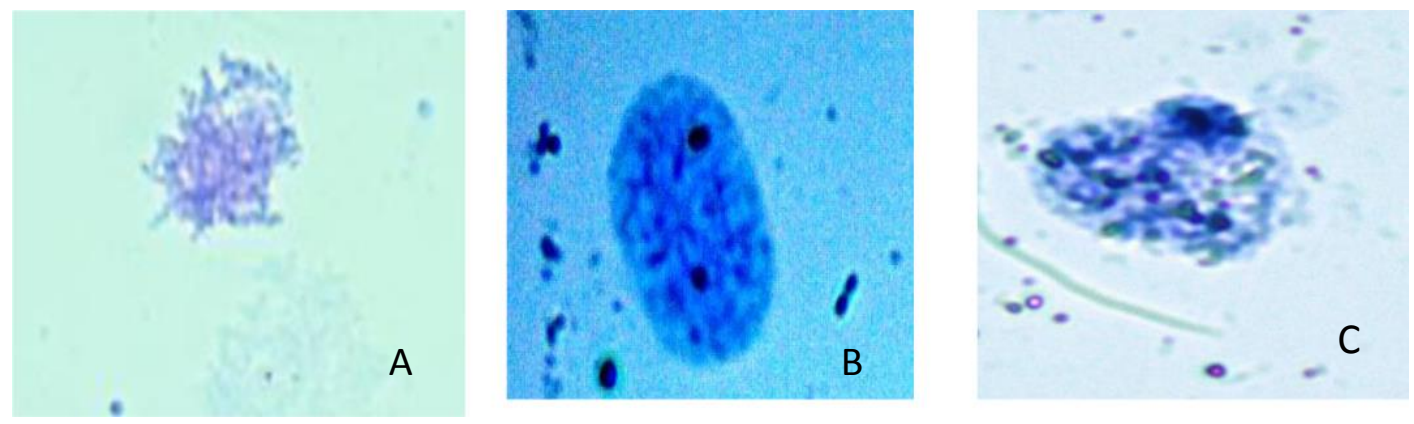

Fig. 2: Light microscope of Biomphalaria alexandrina snails showing, the zygotene stage of meiotic division Biomphalaria alexandrina snails exposed to $\mathrm{LC}_{25}$ of the ethanolic extract of (A) Tecoma stans Moringa oleifera (C) Ziziphus spina christi.

(B) 


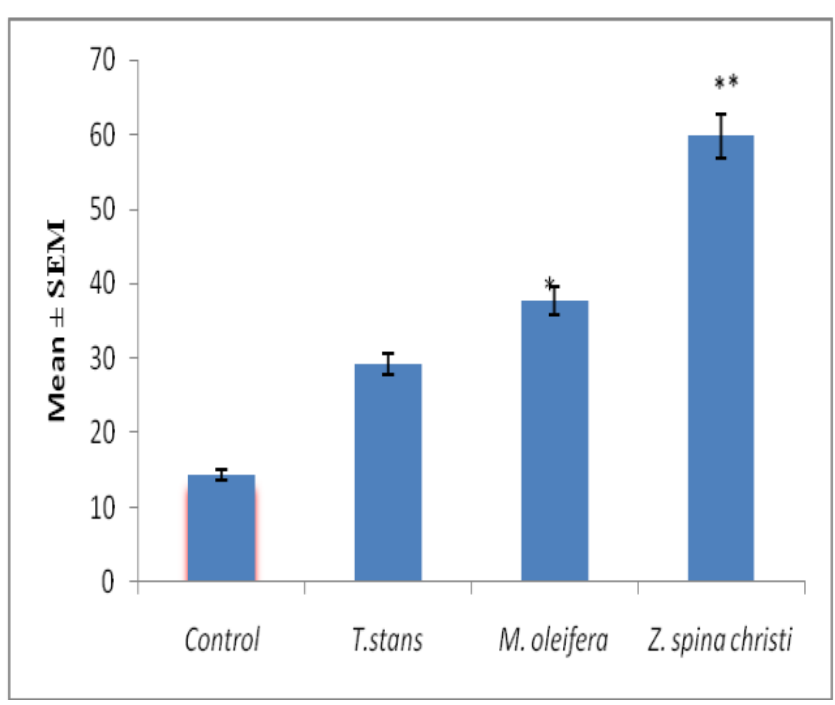

Fig . 3: Percentage of apoptosis Biomphalaria alexandrina snails exposed to $\mathrm{LC}_{25}$ of the ethanolic extract of Tecoma stans, Moringa oleifera and Ziziphus spina christi compared to control group.
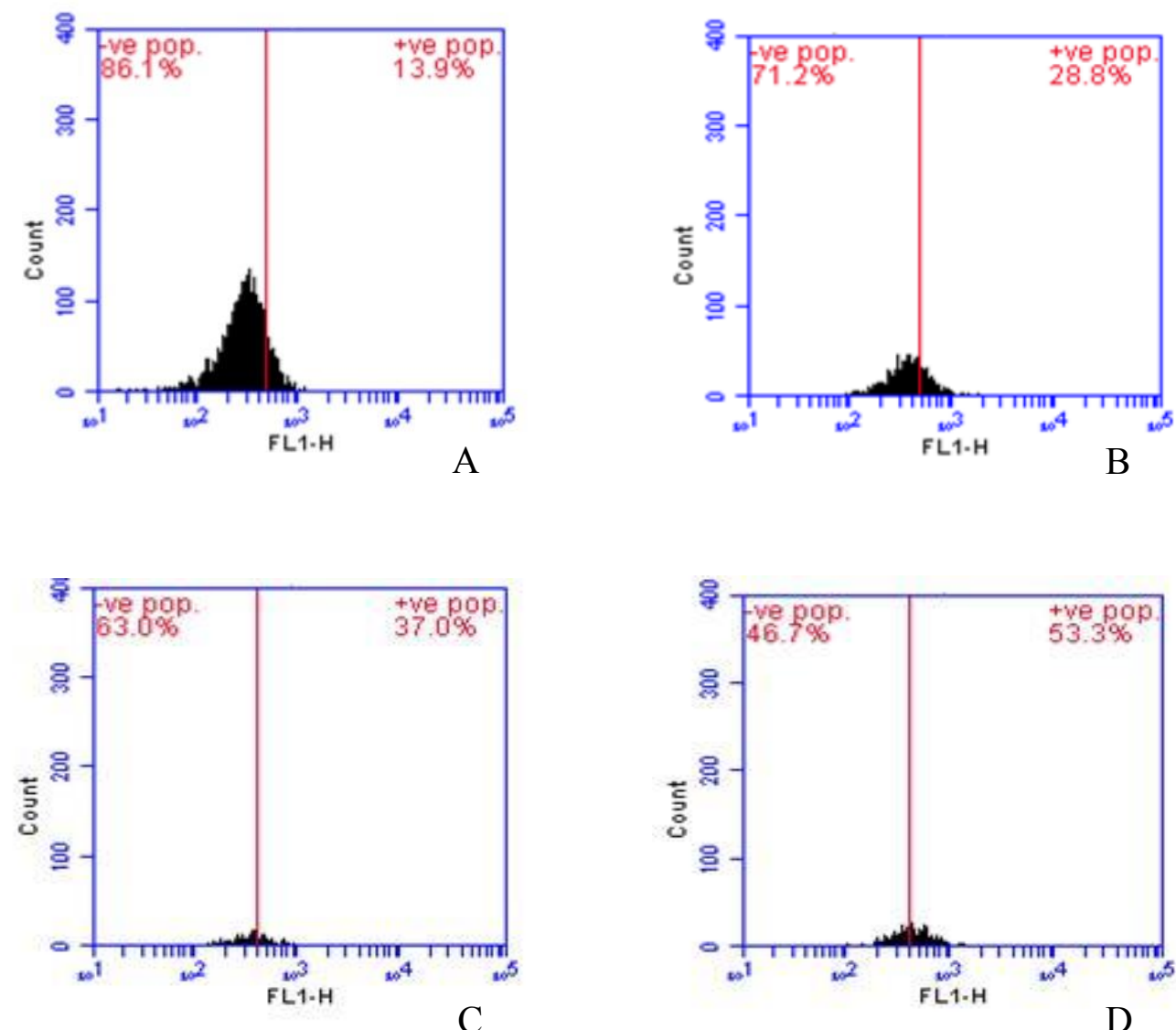

Fig. 4: Flow Cytometric analysis of apoptosis percentage by using annexin V stain labeled with FITC in Biomphalaria alexandrina snails (A) Control , (B) exposed to $\mathrm{LC}_{25}$ of the ethanolic extract of Tecoma stans (C) Moringa oleifera and (D) Ziziphus spina christi . 


\section{DISCUSSION}

The present results verified the presence of the molluscicidal activity of the ethanolic extracts of $Z$. spina christi, $T$. stans, and $M$. oleifera against $B$. alexandrina snails, where, the sub lethal concentrations LC50 were 108.7, 209.4 and $256 \mathrm{mg} / \mathrm{l}$. Ziziphus sp. is used in Egypt for folk treatment of different diseases (Nawash and AlHorani, 2011). The phytochemical composition of Z. spina christi plant indicated the presence of four saponin glycosides and alkaloids as molluscicides (Anthony, 2005). Different extracts of Z.spina christi showed anti-schistosomal activity (El-Rigal et al., 2006) and anti-leishmanial activities (Tonkal et al., 2005).Tecoma stans was known by its antifungal activity and this is due to presence of trypsin inhibitor activity from its leaves (Patriota et al., 2016). Moringa oleifera Lamarck (Family: Moringaceae) is widely distributed in tropical and subtropical regions (Okonkwo et al., 2014). The extract of $M$. oleifera seeds contained bioactive molecules including saponins, lectins, (Ibrahim and Abdalla, 2017) which were known by its molluscicidal activity (Augusto and de MelloSilva, 2018). Francis et al. (2002) reported that the molluscicidal activity of saponins is due to their characteristic detergent effect on epithelial tissues of the snails and that of Flavonoids may act by inhibiting the detoxification system of the snail (de Souza et al., 2014).

Family Planorbidae had large morphological diversity and so it is very interesting in studying the cytogenetic variations (Szabelska et al., 2015) and could be used in systematic analysis of freshwater snails (Tohamy and Mohamed, 2006). The present results showed that in normal control group, the first meiotic division begins with a long prophase (chromatin network) which is subdivided into four stages; leptotene, zygotene, pachytene, and diplotene. The chromatin of the chromatids was stretched out very thinly and the chromosomes were densely stained. The zygotene chromosomes appear to be contracted and darkly stained than the leptotene chromosomes. During the diplotene, the chromosomes were much shorter, more contracted and quite clearly visible. These results in accordance with that of Ibrahim et al. (2018) who described the various meiotic stages, where, early-leptotene and late leptotene, zygotene, diplotene, metaphase were present.

The present results showed that in the exposed B. alexandrina snails, the most observed changes after exposure to the sublethal concentration of each plant extract was the condensation of the chromosomes which was variable in the zygotene stage of each group due to the molluscicidal activity of them on $B$. alexandrina. The most effective plant was $Z$. spina christi followed by $M$. oleifera extract, while, the least effect was $T$. stans extract. These changes may be lead to the cytogenetic alterations of $B$. alexandrina chromosomes as result to the phytochemical composition of $Z$. spina christi plant indicated the presence of four saponin glycosides and alkaloids as molluscicidal, it is important to investigate the possible toxicity of this plant molluscicides extract to aquatic organisms, especially invertebrates. Hence, the use of biological method, affect on snails and not harm to the ecosystem therefore can be used as potent molluscicides to control schistosomiasis.

The current study revealed that the count percentage of apoptosis in exposed snails to ethanolic plant extract of $M$. oleifera and $T$. stans was significantly reduction as compared to ethanolic plant extract of $Z$. spina christi may be correlated to molluscicidal 
activity of $Z$. spina christi, $M$. oleifera and $T$. stans, against $B$. alexandrina snails. Cells are exposed constantly to various genotoxic stresses that can lead to DNA damage. These results were in accordance with Abdel-Haleem, (2013) showed degradation of protein and high intensity of DNA after treatment with methanol extracts in each studied of three plants Euphorbia splendens, Ziziphus spina christi and Ambrosia maritime. Helal et al. (2014) found an increase of the apoptotic cells in infected $B$. alexandrina snails in addition to Shaldoum et al. (2016) used comet assay to confirm the presence of genotoxic effect after using cuprous oxide nanoparticles. Ibrahim and Ghoname, (2018) used comet assay to confirm the presence of genotoxic effect on $B$. alexandrina snails after exposed to aqueous leaves extract of Anagallis arvensis.

\section{CONCLUSION}

The present study indicated that $Z$. spina christi plant was more effective as molluscicidal than $M$. oleifera and that $T$. stans has the less toxic effect on $B$. alexandrina snails. Studying the cytogenetic alterations of $B$. alexandrina chromosomes morphology is of great importance to understand how the plant molluscicides affect these snails. These results have spotlights on the changes of meiotic chromosomes of $B$. alexandrina control and after subjected to the molluscicides and so, these plants can be used as potent molluscicides to control schistosomiasis. Further studies are needed to define the application strategies to not harm the ecosystem.

\section{REFERENCES}

Abdel-Haleem, A. (2013). Comparative karyological studies on the two Egyptian schistosome vectors, Biomphlaria glabrata and Biomphlaria alexandrina, with reference to chromosomal aberrations due to Za'ater plant. Inter. J. Acad. Sci. Res., 1: 1-7.

Anthony, C. (2005). Review of Zizyphus spina christi. WWW. Cornelius. Co, UK.

CDC, (2018). Schistosomiasis - Biology [WWW Document]. URL https://www.cdc.gov/ parasites/schistosomiasis/index.html (accessed 4.29.19).

Augusto, R. and De Mello-Silva, C. (2018). Phytochemical Molluscicides and Schistosomiasis: What We Know and What We Still Need to Learn. Vet. Sci., 5:94. https://doi.org/10.3390/vetsci5040094

Bakry, F.A. and Garhy, M.F. (2011). Comparative study of the karyotypes and electrophoretic patterns of Biomphlaria alexandrina and Bulinus truncatus and the ova of their corresponding trematode hosts. J. Evol. Biol. Res., 3: 22-28.

Burch, J. (1962). Chromosome numbers and systematic in euthyneuran snails; Proc First Eur. Malacol. Cong., 215-241.

De Souza, B.A.; da Silva, L.C.; Chicarino, E.D. and Bessa, E.C. de A. (2014). Phytochemical and molluscicidal activity of Mikania glomerata sprengel (Asteraceae) in different life stages of Subulina octona (Mollusca, Subulinidade). Brazilian Arch. Biol. Technol., 57: 261-268. https://doi.org/10.1590/S1516-89132014000200015

El-Rigal, N. S.; Aly, S. A.; Rizk, M. and Said, A. (2006). Use of Ailanthus altissima and Zizyphus spina-christi extracts as folk medicine for treatment of some hepatic disorders in Schistosoma mansoni infected mice. Trends in medical research, 1: 100-112.

Francis, G.; Kerem, Z.; Makkar, H.P.S. and Becker, K. (2002). The biological action of saponins in animal systems: a review. Br. J. Nutr., 88: 587-605. https://doi.org/10.1079/BJN2002725.

Hayashi, M.T. and Karlseder, J. (2013). DNA damage associated with mitosis and cytokinesis failure. Oncogene, 32: 4593-4601. https://doi.org/10.1038/onc.2012.615

Helal, E.G.; El- Dafrawy, S.M.; Mohamed, A.H.; Abou-El-Nour, B.M.; Abu Taleb, H.M. and 
Ibrahim, S. (2014). Analysis of Circulating Haemocytes from Biomphalaria alexandrina Following Schistosoma mansoni Infection Using Flow Cytometry. Egypt. J. Hosp. Med., 54: 41-53. https://doi.org/10.12816/0002430

Hengartner, M.O. (2000). The biochemistry of apoptosis.Nature, 407:770- 776.

Ibrahim, A.M. and Abdalla, A.M. (2017). Impact of Moringa oleifera seed aqueous extract on some biological, biochemical, and histological aspects of Biomphalaria alexandrina snails. Environ. Sci. Pollut. Res., 24: 28072-28078. https://doi.org/10.1007/s11356-017-0397-0

Ibrahim, A.M. and Ghoname, S.I. (2018). Molluscicidal impacts of Anagallis arvensis aqueous extract on biological, hormonal, histological and molecular aspects of Biomphalaria alexandrina snails. Exp. Parasit., 192: 36-41. https://doi.org/10.1016/j.exppara.2018.07.014

Ibrahim, A.M.; Hammam, O.A. and EL-Dafrawy, S.M. (2018). Infected freshwater snails, Biomphalaria alexandrina, the intermediate host of Schistosoma mansoni. J. Egypt. Soc. Parasit., 48: 503-507.

Ibrahim, A.M. and Sayed, D.A. (2019). Toxicological impact of oxyfluorfen $24 \%$ herbicide on the reproductive system, antioxidant enzymes, and endocrine disruption of Biomphalaria alexandrina (Ehrenberg, 1831) snails. Environ. Sci. Pollut. Res., 26 : 7960-7968. https://doi.org/10.1007/s11356-019-04251-w

Litchfield, J.T. and Wilcoxon, F. (1949). A simplified method of evaluating dose-effect experiments. J. Pharmacol. Exp. Ther., 96: 99-113.

Mostafa, B.B.; El-Khayat, H.M.M.; Ragab, F.M.A. and Tantawy, A.A.A. (2005). Semi field trials to control Biomphalaria alexandrina by different modes of exposure to certain plant and chemical molluscicides. J. Egypt. Soc. Parasit., 35: 925-40.

Nawash, O. and Horani, A.A.S. (2011). The most important medicinal plants in Wadi Araba desert in South West Jordan: a review article | Semantic Scholar. Adv. Environ. Biol., 5: $418-425$.

Okonkwo, N.J.; Nwankwo, E.N.; Ozumba, N.A.; Egbuche, C.M.; Ezugbo-Nwobi, I.K., others (2014). Studies on the invertebrate fauna associated with Moringa oleifera (Lam),(Moringaceae) during the rainy season in Awka, Anambra State, Nigeria. Int. J. Agric. Biosci., 3: 22-25.

Omobhude, M.E.; Morenikeji, O.A. and Oyeyemi, O.T. (2017). Molluscicidal activities of curcumin-nisin polylactic acid nanoparticle on Biomphalaria pfeifferi. PLoS Negl. Trop. Dis. 11: e0005855. https://doi.org/10.1371/journal.pntd.0005855

Park, G. (2011). Karyotypes of Korean endemic land snail, Korean ohadra koreana (Gastropoda: Bradybaenidae). Korean J. Malacol., 27: 87-90.

Park,G.M. and Yong, T.-S. (2014). Karyological Studies of Biomphalaria tenagophila (d'Orbigny, 1835) (Gastropoda: Planobidae) from Rio de Janeiro, Brazil. Korean J. Parasit., 52: 449-451. https://doi.org/10.3347/kjp.

Patriota, L.L.S.; Procópio, T.F.; De Souza, M.F.D.; De Oliveira, A.P.S.; Carvalho, L.V.N.; Pitta, M.G.R.; Rego, M.J.B.M.; Paiva, P.M.G.; Pontual, E. V and Napoleão, T.H. (2016). A Trypsin Inhibitor from Tecoma stans Leaves Inhibits Growth and Promotes ATP Depletion and Lipid Peroxidation in Candida albicans and Candida krusei. Front. Microbiol., 7: 611. https://doi.org/10.3389/fmicb

Rees, C.A.; Hotez, P.J.; Monuteaux, M.C.; Niescierenko, M. and Bourgeois, F.T. (2019). Neglected tropical diseases in children: An assessment of gaps in research prioritization. PLoS Negl. Trop. Dis., 13: e0007111. https://doi.org/10.1371/journal.pntd.0007111

Shaldoum, F.M.; Khaled, M.Z.; Ahmed, M.A.; Sharaf El-Din, T.A. and, Abu-Senna, F.M. (2016). Biomphalaria alexandrina Snails as a Bio-Monitor for Water Pollution using Genotoxic's Effect of Cuprous Oxide Nanoparticles and Copper Sulphate 6: 189-197.

Shapiro, H.M. (2003). Practical flow cytometry. 4th ed.John Wiley \& Sons, Inc, Hoboken, New Jersey. Wiley-Liss. 
Szabelska, A.; Juchno, D.; Spóz, A. and Boron, A. (2015). Mitotic and meiotic chromosomes of the Great Rams Horn Snail Planorbarius corneus ( Linnaeus, 1758) (Gastropoda,

Planorbidae) from Lake Kortowskie. Polish J. Nat., Sci. 30: 47-57.

Thiriot-Quiévreux, C. (2003). Advances in chromosomal studies of gastropod mollusks. J.Moll. Stu., 69: 187-201.

Tohamy, A.A. and Mohamed, S.M. (2006). Chromosomal studies on two Egyptian freshwater snails, Cleopatra and Bithynia (Mollusca-Prosobranchiata). Arab J. Biotech., 9: 17-26.

Tonkal, A. ; Soliman, S. H. ; Jamjoom, B. M. ; Altaieb, M. A. and Al-Bar, A. H. (2005).

Preliminary study on the effect of Ziziphus spina-christi on selected Leishmania species. Sc. J. Az. Med. Fac. (Girls), 26(1): 1915-1921.

Wyllie, A.H. (2010). Where, O death, is thy sting? A brief review of apoptosis biology. Mol. Neurobio., 42: 4-9. https://doi.org/10.1007/s12035-010-8125-5.

\title{
ARABIC SUMMARY
}

\section{تاثير مستخلصات بعض النباتات الطبية كعوامل مبيدة للرخويات و مميتة للخلايا على قواقع}

\section{Biomphalaria alexandrina}

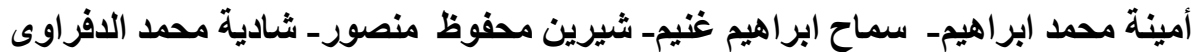

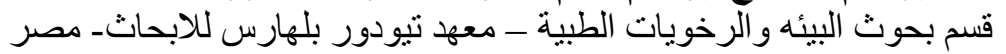 \\ البلهارسيا واحدة من الأمراض المتوطنه التي تحتاج لعائل وسيط لانتقالها وقواقع المياه العذبة العية \\ Biomphalaria alexandrina \\ طريق النباتات الطبية وسيلة واعدة كما انها استر اتيجيا صديقة للبيئة.

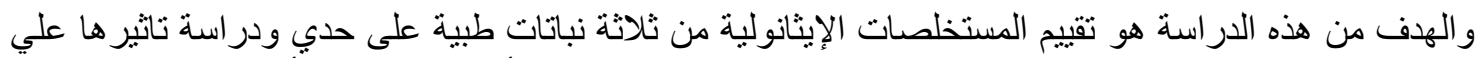

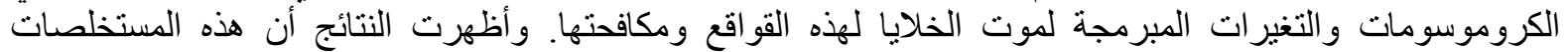

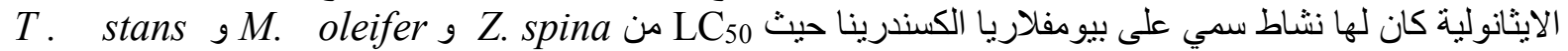

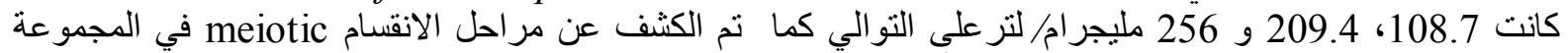 \\ الضابطة ( التي لم يتم تعريضها للنباتات) و تبدأ بطول الَّرحلة الاولى وهى

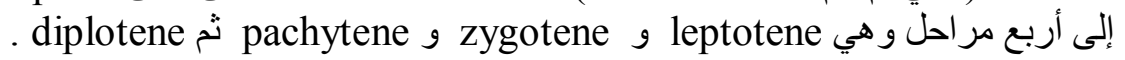 \\ واوضحت هذه الدراسة بعد تعرض قو اقع Biomphalaria alexandrina لهذه النباتات وجود بعض التغيرات في

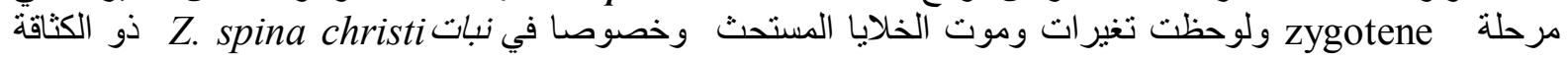

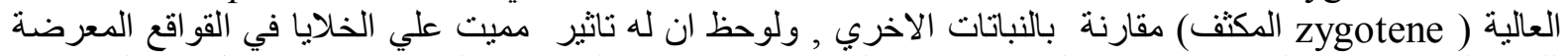

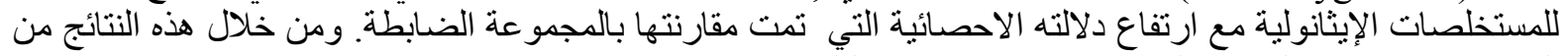

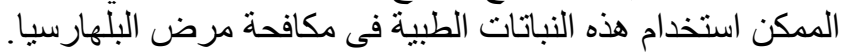

